九州大学学術情報リポジトリ

Kyushu University Institutional Repository

SOME ASIAN SPECIES OF AUSTRONOMIA, A SUBGENUS

OF NOMIA, WITH DESCRIPTIONS OF THREE NEW SPECIES FROM SRI LANKA (HYMENOPTERA, HALICTIDAE)"

Hirashima, Yoshihiro

https://doi.org/10.5109/2382

出版情報: ESAKIA. 12，pp.89-101，1978-11-30. Entomological Laboratory，Faculty of Agriculture， Kyushu University

バージョン:

権利関係 : 


\title{
SOME ASIAN SPECIES OF AUSTRONOMIA, A SUBGENUS OF NOMIA, WITH DESCRIPTIONS OF THREE NEW SPECIES FROM SRI LANKA (HYMENOPTERA, HALICTIDAE)*
}

\author{
YoShIHIRO HiRashima \\ Entomological Laboratory, Faculty of Agriculture Kyushu \\ University, Fukuoka 812, Japan \\ and \\ Hikosan Biological Laboratory, Faculty of Agriculture \\ Kyushu University, Hikosan 824-07, Japan
}

\begin{abstract}
Five species of Nomia(Austronomia) from Sri Lanka are reported, three of which are described as new. New taxa are Nomia (A ustronomia) austella, krombeini and notiomorpha, new species. Notes on Nomia fruhstorferi Pérez of Japan and N. takaoensis Friese of Taiwan are also made. Seven species of Austronomia discussed in this paper are divided into four species groups.
\end{abstract}

Michener (1965) proposed the subgenus Austronomia for the non-metallic and hair-banded Nomia species. Many Australian species are included in this subgenus, some of which are greenish or bluish. He also included to Austronomia some Asian species such as Nomia clypeata Smith, aurata Bingham, pilipes Smith and perlucida Cockerell from India, kankauana Strand from Taiwan, and philippinensis Friese from the Philippine Islands, and suggested, at the same time, that the Indian species antennata Smith and the Japanese species fruhstorferi Pérez may also be included in this subgenus. When I published a monograph or' the Japanese Nominae in 1961, I could not assign fruhstorferi to any subgenus. Thanks to Michener, we are now certain to the position of fruhstorferi.

In relation to my study of Asian Nomia, I received recently a good collection of Nomia of Sri Lanka from Dr. Karl V. Krombein, Smithsonian Institution, Washington, D. C., which was made by him and his collaborators in recent years. Among them I found some interesting species of Austronomia, which was not reported from Sri Lanka before. This paper was written primarily to report a part of the results of my study on the Dr. Krombein's collection of Nomia of Sri Lanka, which was made under the auspices of the

* Contribution from the Entomological Laboratory, Faculty of Agriculture, Kyushu University, Fukuoka (Ser. 3, No. 55), and that from the Hikosan Biological Laboratory, Faculty of Agriculture, Kyushu University, Hikosan (Ser. 2, No. 40). 
Biosystematic Studies of the Insects of Ceylon project of the Smithsonian Institution, Washington, D. C. I am grateful to Dr. Karl V. Krombein for his kind support of my study of the Asian bees.

\author{
K ey to The species groups of the A sian A $\boldsymbol{u}$ stronomia \\ DISCUSSED IN THIS PAPER
}

1. Mesoscutum and scutellum with rather long and fine hairs not concealing integuments; apical margins of basal four terga broadly transparent; hair band on 1 st tergum broadly interrupted in middle; ocelli broadly separated from vertex ; basal area of propodeum distinctly indicated (excavated, longitudinally carinate on interior, carinate behind at least on lateral portions) ; male unknown $\ldots \ldots \ldots \ldots \ldots \ldots \ldots \ldots \ldots \ldots \ldots \ldots \ldots \ldots \ldots \ldots \ldots \ldots \ldots \ldots$ Group of fruhstorferi Pére $z$ Mesoscutum and scutellum with very short, very dense and densely branched hairs often concealing integuments; hair band on 1st tergum complete; basal area of propodeum poorly indicated, not at all excavated; face of female

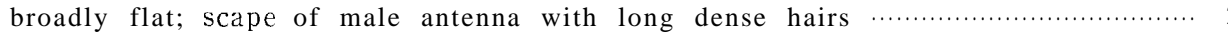

2. Length about 8. $5 \mathrm{~mm}$ or smaller; hairs on thorax above fulvous. Female: ocelli close to summit of vertex; basitibial plate sharply pointed at apex; inner hind tibial spur slightly shorter than the outer. Male : hind femora extraordinarily swollen; hind tibiae also thickened, with one spur at apex; tarsi of all legs pale except for claw-segments which are black; underside of thorax with a pair of conical projections in front of mid coxae.

Group of takaoensis Friese

Smaller, about or less than $8 \mathrm{~mm}$; hairs on thorax variable in color; ocelli very close to summit of vertex in female; hind femora of male at most moderately swollen; hind tibiae of male also not strongly thickened, with two

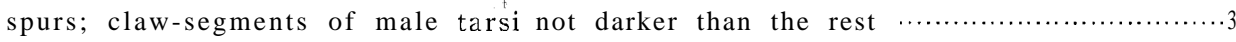
Length about $8 \mathrm{~mm}$ or smaller; thorax above with fulvous hairs. Male: hind trochanters with a flange of curved projection; underside of thorax with a pair of flat, triangular, posteriorly projecting processes between mid coxae; hind tibiae and tarsi moderately swollen; apical margin of 4 th sternum sclerotized at least in middle..................................... Group of ustula Cockerell

Very small species, length less than $7 \mathrm{~mm}$; hairs on thorax above grey to pale fulvous, not well concealing integuments; hind trochanters of male normal; underside of thorax of male without any projection; apical margin of male 4th sternum not at all sclerotized, broadly pale ferruginous transparent

Group of krombeini, new species

\title{
1. Species group of Nomia fruhstorferi Pérez
}

At present, two species are included in this group. Unfortunately, the males of them are unknown. It is very probable that this group is divided into two when the males of them were discovered and their characters were disclosed. This group may be characterized as follows based on the females.

Posterior ocelli broadly separated from summit of vertex; integuments of mesoscutum and scutellum not concealed by hairs which are rather long and fine, as usual; basal area of propodeum distinctly indicated, carinate behind at least on lateral portions, interior of basal area longitudinally carinate at 
least on lateral portions; apical margins of basal four terga broadly discolored and transparent; broad apical depressions of three basal terga well indicated, at least on lateral portions; hair band on 1st tergum very broadly interrupted in middle.
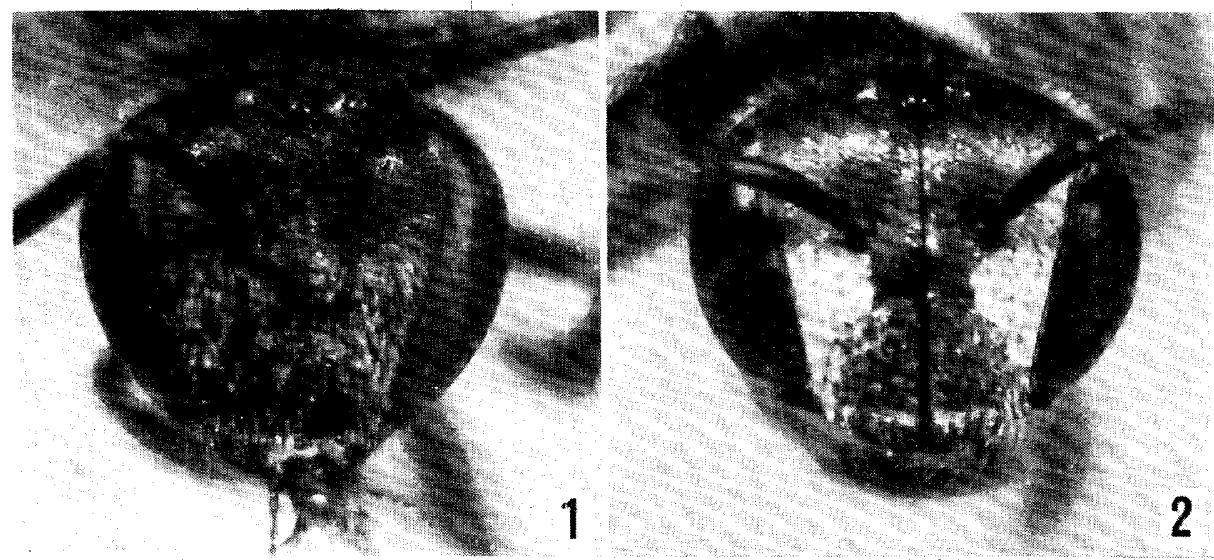

Figs. 1 and 2. Frontal view of the female head of (1) Nomia (Austronomia) fruhstorferi Pérez and (2) Nomia (Austronomia) austella, new species.

This group is heterogeneous in the following points:

Head transverse (austella, new species) or round (fruhstorferi) in frontal view ; clypeus normal (fruhstorferi) or very strongly convex with median longitudinal keel ; supraclypeal' area with impunctate space in middle (austella) or entirely densely punctate ; collar of pronotum linear (fruhstorferi) or slightly broadened on lateral portions ; tegulae small (fruhstorferi) or large ; stigma short (austella) or long; basitibial plate small and rounded at apex (austella) or large and more or less pointed at apex; hind tibia1 spurs about equal in length and not hook-like at each apex (fruhstorferi) or distinctly different to each other in length and pectination; punctures on metasoma very distinct (fruhstorferi) or virtually absent.

\section{Nomia (Austronomia) fruhstorferi Perez}

Nomia fruhstorferi : Michener, 1965, Bull. Amer. Mus. Nat. Hist., 130: 157.

This species is known from Japan, and this is the northernmost record of Austronomia. This is not a common species there and the male is still unknown.

Mesoscutum very densely punctate on smooth and shining ground; propodeum with basal area well indicated, narrow, transverse, longitudinally carinate on interior, posterior margin not carinate in middle; basitibial plate large, triangular, pointed at apex but not sharply so; inner hind tibia1 spur well curved, neither serrate nor pectinate, about as long as outer one; both tibia1 spurs similar in shape and not hook-like at each apex.

Distribution : Japan. 


\section{Nomia (Austronomia) austella, new species}

Unfortunately this new species is known by the holotype female only. This is easily separable from fruhstorferi by the characters stated above.

Female: Length about $8.5 \mathrm{~mm}$; fore wings about $6 \mathrm{~mm}$.

Very robust species. Relative head measurements : width, 44; length, 36; eye length, 27; upper interocular distance, 26; width of face, 29 ; lower interocular distance, 22. Vertex roundly well convex when head is seen in front; eyes rather large; inner eye margins not strongly converging below except for upper about one-fourth which converges toward ocelli; clypeus strongly convex longitudinally, with median, longitudinal, strong keel ; supracly. peal area well convex, with median, longitudinal, shining impunctate line which is slightly broadened in middle; frontal line well indicated, more distinct on upper portion of supraclypeal area; thus, face with a median longitudinal line from apex of clypeus to mid ocellus ; frons well convex; ocelli broadly separated from summit of vertex; postocellar distance about equal to ocellocular distance, about twice as long as ocelloccipital distance; genal area much narrower than eye as seen from side. Thorax broad ; mesepisternum strongly convex; propodeum short, posterior face steep; basal area of propodeum well indicated, carinate behind, interior shining, longitudinally carinate on lateral portions. Stigma of fore wing small, much shorter that in fruhstor. feri; tegulae large, distinctly larger that in fruhstorferi. Legs stout; basitibial plate small, rounded at apex; inner spur of hind tibia densely serrate, slightly curved inward, and slightly curved at apex, but not hook-like; outer spur of hind tibia unusually long, much longer than inner one, minutely and densely serrate (x 64), apex sharply curved and hook-like ; hind basitarsus broad, about twice as long as broad except for apical brush. Metasoma very broad; apical depression of terga not well indicated; apical margin of 2nd sternum distinctly emarginate in middle, so that the sternum short in middle.

Clypeus strongly, longitudinally rugoso-punctate, punctation becoming stronger toward apex, spaces between punctures shining; supraclypeal area more finely and densely punctate except for median, slightly elevated, shining area; frons weakly shining, very densely and finely punctate, punctures not stronger than those on supraclypeal area; impunctate shining spaces in front of mid ocellus and lateral to posterior ocelli; vertex shining, with weak, not dense punctures. Mesoscutum very densely punctate on microscopically roughened (nearly tessellate), weakly shining ground, punctures small ; scutellum slightly more roughened, less shining, with punctures slightly smaller. Metasomal terga weakly shining, microscopically shagreened, without distinct punctures.

Black; mandible reddened apically; flagellum yellowish brown beneath except for 1st segment; tegulae pale ferruginous subhyaline ; wings slightly darkened; veins and stigma yellowish brown except for subcosta which is brown; legs piceous, yellowish on each apex and base of fore and mid tibiae, and yellowish brown on small segments of tarsi; spurs pale ferruginous; apical 


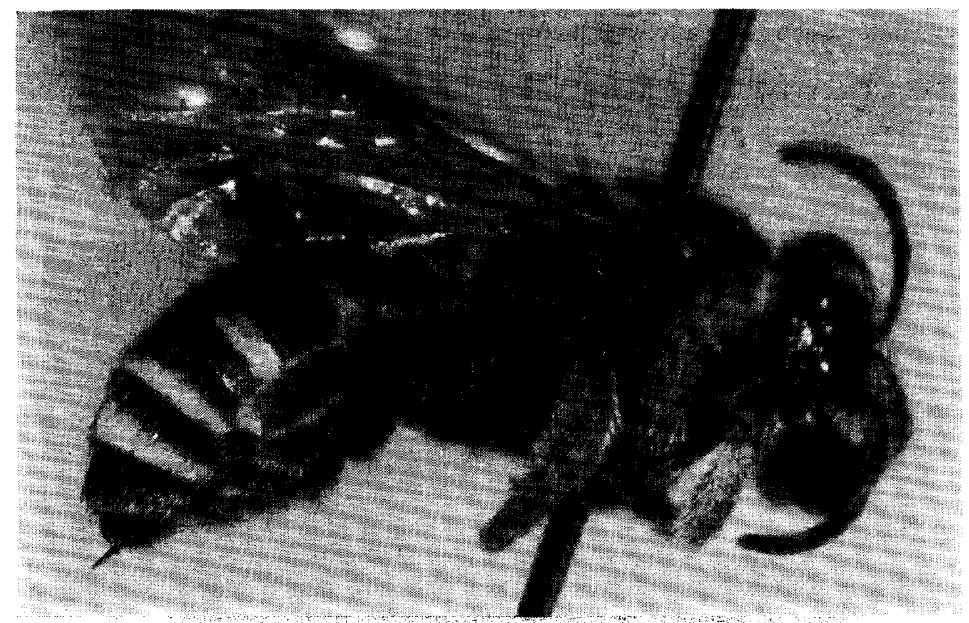

Fig. 3. Nomia (Austronomia) austella, new species, the holotype female.

margins of four basal terga broadly discolored and hyaline.

Head rather hairy; hairs on head white; side of face with dense, densely branched, downy, and silvery hairs; collar of pronotum and lateral lobe of pronotum densely covered with short, scale-like, white (slightly yellowish) hairs; mesoscutum with white (very slightly yellowish) hairs not concealing surface; posterior margin of mesoscutum with a narrow band of densely branched, short, dull white (slightly yellowish) hairs; metanotum densely covered with hairs similar to pronotum; propodeal corbicula distinct, with long hairs; posterior face of propodeum with appressed, densely branched, white hairs in addition to erect, more or less long, yellowish hairs; thorax with no dark hairs; tibial scopa silvery, composed of rather short, not much branched hairs; metasoma with white hair band entire on 4th tergum, entire but sparse in middle on 3rd, broadly interrupted on 2nd, and more broadly interrupted on 1st; hairs on 5th tergum brown medially, not specially dense, and not well arranged in a compact fringe; hairs on venter ochreous.

Type material and type depository: Holotype female, Palatupana Tank, Ham. Dist., Sri Lanka, February 3-4, 1975, Malaise trap (K. V. Krombein, P. B. Karunaratne, P. Fernando, E. G. Dabrera), in the Smithsonian Institution, Washington, D. C.

Distribution : Sri Lanka,

\section{Species group of Nomia tukaoensis Friese}

So far as I know, this species group is composed of but one species, Nomia takaoensis Friese. It was described originally from Taiwan, but it is widely distributed in Asia. Nomia kankauana Strand, 1913, from Taiwan, is probably regarded as a synonym of takaoensis. A subspecies, philippinensis, has been described from the Philippines (Cockerell, 1915). I have seen a number of 
specimens from Fukien, China, in the collection of the Bishop Museum (Honolulu) and from Thailand in our collection at the Kyushu University. I think the populations in Fukien and Thailand represent a new subspecies respectively. Detailed discussion of this species group may be appeared in a separate paper. No species from Sri Lanka.

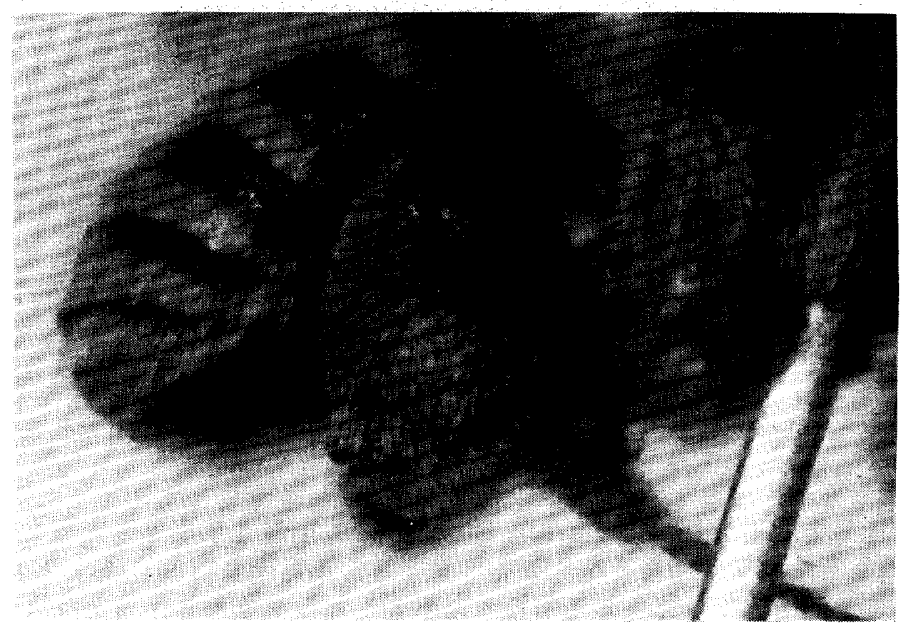

Fig. 4. Nomia (Austronomia) takaoensis Friese, the posterior part of the male body, specially showing the extraordinarily convex hind femur.

Diagnostic characters of this group are as follows:

Rather small (length about $8.5 \mathrm{~mm}$ or smaller), robust species; hairs on mesoscutum and scutellum fulvous, very short, dense, and densely branched, often becoming deeper in color toward scutellum; metasomal hair bands complete, four in female and five in male (hair band of male 1st tergum sometimes sparse in middle) ; basal area of propodeum not well indicated; punctures on metasomal terga very weak in female, more distinct (although very small) in male.

Female: Head transverse in frontal view, thin, especially so on upper portion as seen in profile; face broadly flat; inner eye margins strongly converging below except for upper about one-fourth which also strongly converges toward ocelli ; posterior ocelli just below summit of vertex; basitibial plate pointed at apex; inner hind tibial spur densely pectinate, apex sharply curved and hook-like, about as long as outer one which is not pectinate and apex distinctly curved but not hook-like.

Male: Face densely covered with downy, densely branched hairs; scape with long dense hairs; posterior ocelli well below summit of vertex; 1st segment of flagellum longer than broad, about as long as next segment; underside of thorax with a pair of conical projections in front of mid coxae; hind femora extraordinarily convex; hind tibiae also strongly swollen, with but one apical spur; hind tarsi long and slender; tarsi yellowish or nearly ferruginous except for claw-segments which are black; apical margin of 4th sternum deeply emarginate in middle and well sclerotized. 


\section{Species group of Nomia ustula Cockerell}

This group may be named as the species group of Nomia scutellata Smith, because, according to the literature, Nomia ustula described from Sri Lanka is very close to the Indian Nomia scutellata Smith, which has been described earlier than ustula. Since I have not seen any Indian specimen of Nomia scutellata Smith, I adopt ustula for the name of this group at present.

So far as Sri Lanka is concerned, this species group is composed of two species, which are very close to each other and only separable, with certainty, by the male characters.

Group of small (about $8 \mathrm{~mm}$ or smaller), robust species. Female: very similar to the preceding group, but posterior ocelli more close to summit of vertex (also close to summit of vertex in the preceding group) ; outer hind tibial spur longer than inner one (slightly longer in the preceding group). Male: posterior ocelli also closer to summit of vertex than in the takaoensis group; underside of thorax with a pair of flat, triangular, posteriorly projecting processes between mid coxae; hind trochanters with a flange of curved process; hind femora only slightly swollen; hind tibiae also slightly swollen, longer that in the takaoensis group, inner apical corner triangularly strongly projected, with two apical spurs.

K EY to THE MALes of the ustula group OF SRI LANKA

1. Hind femora convex, most highly elevating beyond middle as seen in profile; triangular apical projection of hind tibiae not large, basal portion of apical margin constricted, brown or slightly more paler (then slightly yellowish) in color ("chestnut-colored" in the original description); legs piceous to brownish, not pale-colored except for fore tarsi and basal portions of hind hasitarsi occasionally pale; apical margin of 4 th sternum deeply emarginate in middle, well sclerotized and transverse; 6th tergum, which is often retrac-

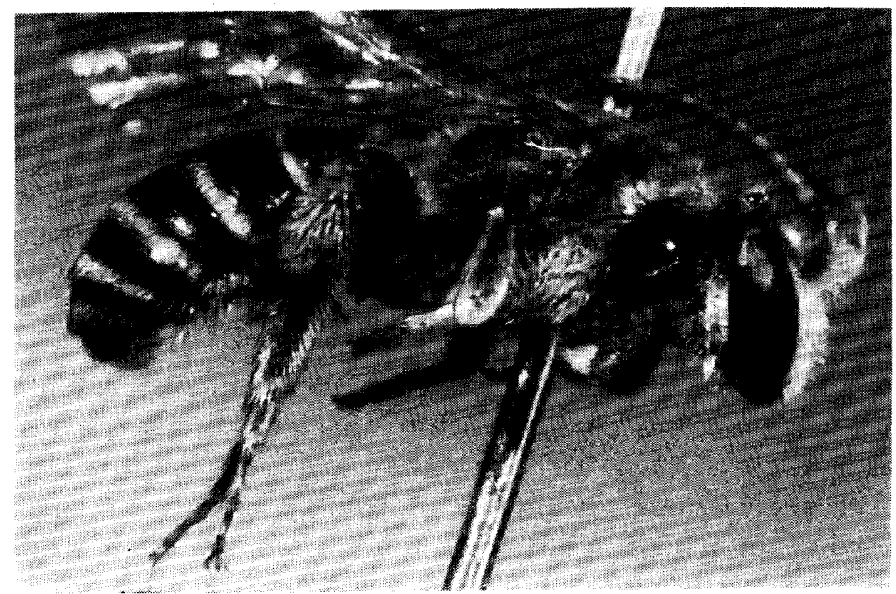

Fig. 5. Nomia (Austronomia) ustula Cockerell. male. 
tile, with brown or brownish hairs predominant ustula Cockerell

- Hind femora distinctly convex, most highly elevating in middle as seen in profile; triangular apical projection of hind tibiae very large, not constricted basally, pale yellowish and subtransparent in color; legs also pale yellowish on the following portions: fore tarsi, fore tibiae except median portions, mid tarsi, both ends of mid and hind tibiae, and basal halves of hind basitarsi; apical margin of 4 th sternum emarginate in middle, not transverse but flat v-shaped; 6th tergum with hairs white but occasionally with slightly brownish hairs on median portion of apical margin ................ (Austronomia) sp.

\section{Nomia (Austronomia) ustula Cockerell}

Nomia ustula Cockerell, 1911, Trans. Amer. Ent. Soc. 37: 231, male (type) and female. Ceylon.

The male of this species is well described by Cockerell so that the identification of it is rather easy and is clearly separated from its close relative, which is undetermined, as shown in the key. I can not recognize, however, the female of this species with certainty. Fourteen female specimens before me in the Krombein's collection may be divided into two groups by the proportion of the head in the frontal view (head short and more transverse in three females), but I do not know which is which, if they are separate. The material taken from the same nest will be needed to prove the matter. I have seen 9 male specimens of ustula from various localities in Sri Lanka, as stated below.

Specimens examined: 2 males, Ratunapura, Rat. Dist., Ceylon, Oct. 18, 1969 (Krombein and Karunaratne) ; 1 male, Wildlife Soc. Bungalow, Hunuwilagama, Wilpattu, Anu. Dist., Ceylon, Mar. 10-19, 1970 (Davis and Rowe) ; 1 male, Irrigation Bungalow, Padaviya, $180 \mathrm{ft}$., Anu. Dist., Ceylon, Feb. 27-Mar. 9, 1970 (Davis and Rowe) ; 1 male, without the head, Pimburettawa, 13 mi. S. Mannampitiya, 1850', Pol. Dist., Ceylon, Nov. 9-12, 1970 (0. S. Flint, Jr.) ; 1 male, Kandy, Kandy Dist., Ceylon, Feb. 1-15, 1971 (Piyadasa \& Somapala) ; 1 male, Labugama Reservoir Jungle, Col. Dist., Sri Lanka, Oct. 13-14, 1973 (Krombein et al.) ; 1 male, Udawattakele, Kandy Dist., Sri Lanka, Oct. 1-13, 1973, at black light (Krombein et al.) ; 1 male, Gilimale Jungle, Rat. Dist., Sri Lanka, July 17, 1976 (Krombein et al.).

Distribution : Sri Lanka.

Nomia (Austronomia) sp.

As shown above, the female of this species is not separable from that of the preceding species. The male of this species is clearly separable from that of the preceding species, although they are very similar in the general habitus. I have seen 8 male specimens of this species from various localities in Sri Lanka, some of which are taken simultaneously with ustula. I do not know whether this is the male of Nomia scutellata Smith or not.

Specimens examined: 1 male, Parayanalankulam, Vav. Dist., Ceylon, Oct. 
22, 1969 (Krombein and Karunaratne) ;2 males, Arakawila Jungle, Padukka, Col, Dist., Ceylon, Dec. 10, 1969 (P. B. Karunaratne) ;1 male, Hambantota, 10', Ceylon, Oct. 28, 1970 (0. S. Flint, Jr.) ; 2 males, Hasalaka, 500', Kan. Dist., Ceylon, Nov. 21-25, 1970 (0. S. Flint, Jr.) ;1 male, 5mi. NW. Mahiyangana, Malaise trap at Hasalaka Irrigation Bungalow, Kan. Dist., Ceylon, Mar. 30April 9, 1971 (P. \& P. Spangler) ; 1 male, Kalatuwawa, Col. Dist., Sri Lanka, Aug. 6-11, 1975 (Huang et al.).

Distribution : Sri Lanka.

\section{Species group of Nomia krombeini, new species}

This is composed of two, very small species of Sri Lanka. I have never seen such a small species of Nomia, not Rhopalomelissa, like these species. For the generic characters of Rhopalomelissa, see Hirashima (1961).

The two species of this group, krombeini and notiomorpha, new species, are very similar to each other, and the females of them are separable only by slight difference of the color of the hairs on the thorax and metasoma. I have seen 117 specimens in total of this group from Sri Lanka, which are divided into two species as follows: krombeini, new species, 46 specimens (40 females and 6 males) and notiomorpha, new species, 71 specimens (60 females and 11 males). Interestingly, the holotype series of both species were collected simultaneously.

Female: Very similar to the preceding group except for hairs on mesoscutum and scutellum not quite concealing integuments, although they are very short and well branched.

Male: Hairs on mesoscutum and metanotum also not quite concealing surface; hind femora and tibiae only slightly swollen; at least hind legs pale ferruginous ; 4th sternum broadly pale ferruginous transparent, apical margin not emarginate (only slightly emarginate in middle in notiomorpha, ne w species), and not at all sclerotized.

KEY TO THE SPECIES OF THE $k$ rombeini GROUP

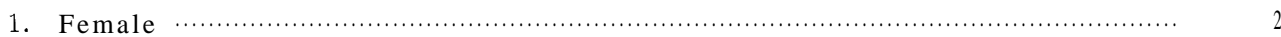

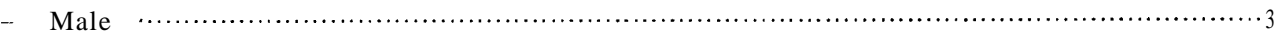

2. Hairs on thorax above and basal terga yellowish grey; hair bands on basal three terga also slightly yellowish, at least on median portions; hair band

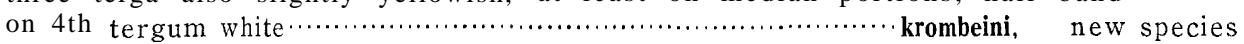

- Hairs on thorax above grey; tergal hair bands white, and hairs on basal

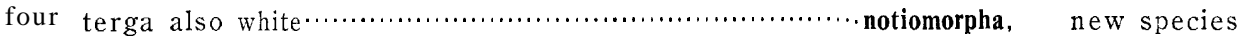

3. Hairs on head, thorax above and metasoma including hair bands distinctly yellowish; hind femora slightly swollen; hind tibiae also slightly swollen, with thin, lamella-like, long apical lobe which has two curved slurs; hind basitarsi rather distinctly swollen; apical margin of 4th sternum not emarginate in middle; legs broadly ferruginous …........................... krombeini, new species

- Hairs on head, thorax above and metasoma yellowish grey; hind femora normal or only very slightly swollen; hind tibiae also very slightly swollen, 
with small, triangular apical lobe which also has two curved spurs; hind basitarsi slender, not swollen; apical margin of 4th sternum slightly emarginate on median portion; hind tarsi with apical four segments brownish, darker than pale basitarsi …....................................... notiomorpha, new species

\section{Nomia (Austronomia) krombeini, new species}

Probably this is one of the smallest species of Nomia in the world. Many species of Rhopalomelissa have been described as Nomia, but it is very certain that this species has never been described in any genus.

Female: Lenght about $6.5 \mathrm{~mm}$; fore wings slightly less than $5 \mathrm{~mm}$.

Relative head measurements : width, 36; length, 27 ; eye length, 22; upper interocular distance, 22 ; width of face, 25.8; lower interocular distance, 16. Inner eye margins strongly converging below except for upper about one-fourth which also strongly converging toward ocelli; thus, emargination of inner eye margins strong; posterior margins of posterior ocelli almost on summit of vertex; postocellar distance slightly shorter than ocellocular distance (5. 5: 6.0) ; face only slightly convex as seen in profile, broadly flat in frontal view. Collar of pronotum linear; basal area of propodeum very poorly indicated, not distinctly sculptured. Wings with 3rd submarginal cell longer that 1st; stigma slender, not large; tegulae more or less large for size of thorax. Legs stout as usual ; basitibial plate moderately large, almost triangular, apex pointed; hind tibiae more or less short, distinctly widened toward apices, inner hind tibia1 spur distinctly pectinate, apex sharply curved and hook-like; outer hind tibia1 spur longer than the inner, without tooth, apex also sharply curved and hook-like; hind basitarsi moderately broad, apical brush small, brushbearing portion distinctly produced beyond basal joint of 2nd segment. Metasoma oval as usual.

Clypeus and supraclypeal area extremely densely punctate; rest of face also similarly punctate but punctures smaller; vertex and ocellocular space slightly shining, minutely roughened with indication of very weak punctures;
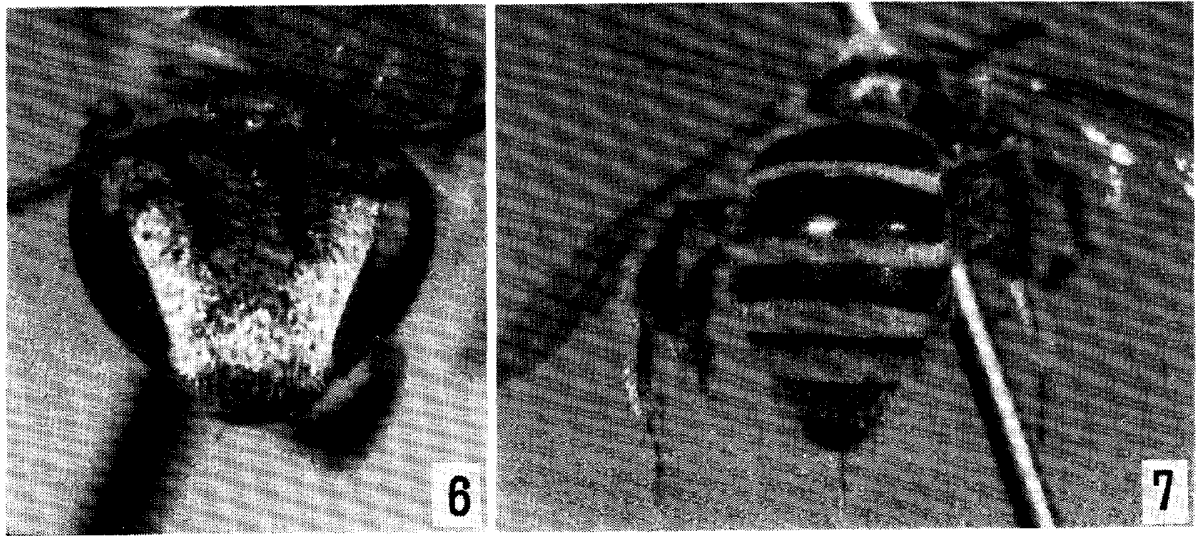

Figs. 6 and 7. Nomia (Austronomia) krombeini, new species. 6: Frontal view of the female head. 7: Posterior view of the female metasoma. 
impunctate, not distinctly shining space lateral to posterior ocellus. Mesoscuturn and scutellum dull, extremely densely punctate, punctures very small; propodeum minutely roughened, dull. Metasoma weakly shining; 1st tergum minutely shagreened, impunctate ; 2nd tergum similar to 1st but with micropunctures in larger individuals; 3rd slightly more roughened, without distinct punctures,

Hairs on head yellowish, glistening in some light, sometimes hairs on head silvery ; hairs on thorax above yellowish grey ; hairs on mesoscutum and scutellum not quite concealing integuments although they are very short, dense and well branched; tibial scopa well developed, whitish, hairs on outer face well branched; hairs on basal terga yellowish grey; hair bands on basal three terga also slightly yellowish on median portions; 4th hair band white; hairs on 5th tergum fuscous; venter with hairs yellowish grey or pale ochreous, without darker hairs.

Black; mandible broadly reddened apically; flagellum beneath reddish brown except for 1st segment; tegulae pale ferruginous subhyaline except for extreme bases; wings slightly darkened; veins and stigma yellowish brown except for subcosta which is brownish; legs piceous, partly brownish or more paler; basal portions of fore and mid tibiae often pale yellowish brown.

Male: About equal to female in length but slenderer.

Relative head measurements : width, 35.5; length, ca. 28; eye length, 22; upper interocular distance, 22; width of face, 24.5; lower interocular distance, 14.5. Inner eye margins strongly converging below like female; unlike female, ocelli well separated from summit of vertex; scape moderately long, slightly shorter than three basal segments of flagellum together; flagellum long, with 1st segment slightly enlarged, about as long as broad, 2nd slightly longer than broad, about as long as 3rd which is slightly longer than 4th. Legs

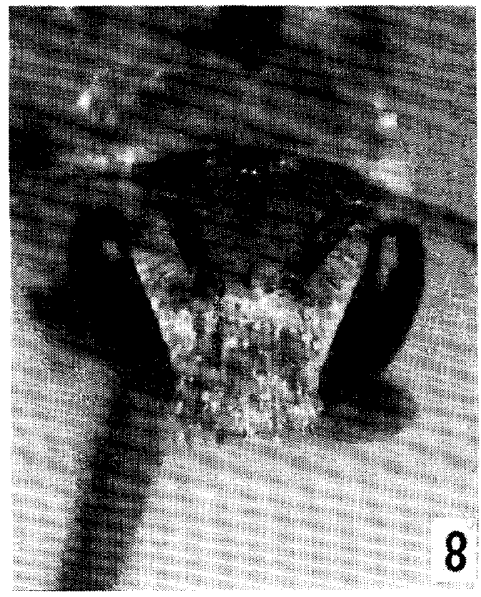

Figs. 8 and 9. Nomia (Austronomia) head. 9: Lateral view of the male.

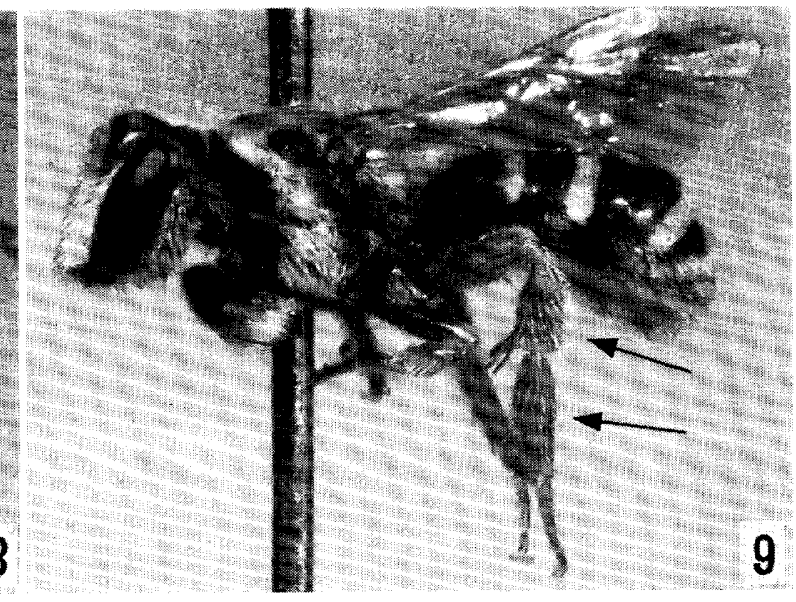

krombeini, new species. 8: Frontal view of the male Note the hind tibia and tarsus which are slightly swollen. 
more or less stout; hind femora slightly swollen; hind tibiae also slightly swollen, with thin, narrow, long, lamella-like apical projection ; apical portion of apical margin, which is base of apical projection, of hind tibia broadly constricted; two apical spurs of hind tibia not long, delicately curved ; hind basitarsi also swollen and broad. Metasoma long elliptical; apical margins of terga distinctly depressed, apical depression of 1st tergum narrow in middle; 2nd tergum with basal portion distinctly constricted, and median portion transversely well convex ; 3 rd and 4th terga also well convex, with broader apical depressions ; apical margin of 4 th sternum not emarginate, not at all sclerotized.

Upper portion of head with punctures more distinct and closer than in female; mesoscutum and scutellum punctate as in female; propodeum, except for basal area, rather densely punctate, but punctures very small; 1st tergum with dense, very small punctures; 2nd tergum more distinctly and more densely punctate than in 1st; 3rd also densely punctate.

Hairs on body distinctly yellowish, brighter than those of female; face densely covered with downy, densely branched, golden hairs; scape with long, dense, yellowish hairs except for posterior portion; very short, dense, densely branched hairs on mesoscutum not quite concealing intequment; basal five terga with complete hair bands.

Black; mandible pale yellowish, red apically; scape and pedicel black ; flagellum broadly yellowish beneath, brown above; tegulae and wings slightly paler than in female; legs ferrugenous except for coxae and trochanters of all legs and femora of fore and mid legs; fore and mid tibiae with obscure brownish markings.

Type material and type depository: Holotype male, 4 paratopotype males and 23 paratopotype females, Wildlife Soc. Bungalow, $200 \mathrm{ft}$., Hunwilagama, Wilpattu, Anu. Dist., Ceylon, Mar. 10-19, 1970 (Davis and Rowe) ; 1 male and 5 females, Hambantota, Ham. Dist., Ceylon, Oct. 28, 1970 (0. S. Flint, Jr.) ; 1 male (No. 32877 C), Museum Gardens, $50 \mathrm{ft}$., Colombo, Sri Lanka, March 28, 1977 (P. B. Karunaratne), all in the Smithsonian Institution, Washington, D. C.

Other material: 16 females from various localities in Sri Lanka, in the collection of the Smithsonian Institution, Washington, D. C.

Distribution : Sri Lanka.

This species is named in honor of Dr. Karl V. Krombein who is one of our close friends for many years.

\section{Nomia (Austronomia) notiomorpha, new species}

The female of this species is only separable from that of krombeini by the color of the hairs on the thorax and the metasoma, as shown in the key. In addition, the long, sparse, erect hairs on the mesoscutum and the scutellum are darker than in krombeini, slightly to rather distinctly brownish, while they are only brownish on the scutellum only in krombeini.

The male of this species is separated by the characters of the hind legs 
and the 4th sternum, as shown in the key. In addition, the hairs on the body are less yellowish and the legs are more darkened than in krombeini.

Type material and type depository: Holotype male, 2 paratopotype males and 28 paratopotype females, same data as the holotype of krombeini; 2 males and 2 females, Irrigation Canal, Parayanalankulam, 25mi. NW. Medawachchiya, $100 \mathrm{ft}$., Vav. Dist., Ceylon, March 20-25, 1970 (Davis \& Rowe) ; 1 male and 1 female, Hasalaka, 500', Kan. Dist., Ceylon, Nov. 22-25, 1970 (0. S. Flint, Jr.) ; 1 male, Hambantota, 10', Ham. Dist., Ceylon, Oct. 28, 1970 (0. S. Flint, Jr.) ; 1 male, 5 mi. NW Mahiyangana, Kan. Dist., Ceylon, Mar. 30-Apr. 9, 1971 (P. \& P. Spangler) ; 1 male, Ekgal Aru, Amp. Dist., Sri Lanka, June 12, 1976 (Krombein et al.) ; 1 male, Reservoir Jungle, Ekgal Aru, Amp. Dist., Sri Lanka, June 9-11, 1976 (Krombein et al.) ; 1 male, Udawattakele Sanctuary, $2100 \mathrm{ft}$., Kandy, Sri Lanka, Sept. 20-27, 1976 (S. Karunaratne), all in the Smithsonian Institution, Washington, D. C.

Other material: 29 females from various localities in Sri Lanka, in the collection of the Smithsonian Institution, Washington, D. C.

Distribution : Sri Lanka. 